\title{
EXPERIENCE WITH SELF INTERMITTENT CATHETERISATION FOR WOMEN WITH NEUROLOGICAL DYSFUNCTIONS OF THE BLADDER
}

\author{
By Elizabeth Joiner, R.N. and Rosemary Lindan, M.B., B.S.(London) \\ Cuyahoga County Hospital, Highland View, Cleveland, Ohio, U.S.A.
}

\begin{abstract}
Twenty-four women with neurological dysfunctions of the bladder were trained in the technique of self intermittent catheterisation (SIC). Although all of them mastered the technique, four patients had to be discontinued from the programme for various reasons while still hospitalised and three others elected to return to Foley drainage, for reasons of convenience, after discharge home.

The infection rate during SIC is low and most women welcome the advantage of freedom from drainage apparatus or diapers. However, patients must be both well motivated and independent in transfers to be able to continue indefinitely with such a programme.
\end{abstract}

Key words: Urinary catheterisation; Neurological dysfunction of bladder; (Bladder, neurogenic-Index Medicus, U.S.A. listing).

\section{Introduction}

STERILE intermittent urethral catheterisation has been used for 25 years as a means of initial management of patients with neurological dysfunction of the bladder (Guttmann \& Frankel, I966). It later came into wide use as a bladder retraining technique during the rehabilitation phase of patients with neurological disease who had been wearing Foley catheters (Bors, 1967; Comarr, 1972; Lindan \& Bellomy, I975; Firlit et al., I975; Perkash, 1975). Nearly Io years ago Lapides (I972) and his co-workers introduced the concept of self intermittent catheterisation (SIC), using so-called 'clean' techniques, as a permanent method of emptying the bladder for patients with various neurological diseases. This approach was found to be of particular value in children of both sexes with meningomyelocele where it seemed to offer an alternative to the need for ureteral diversions or diapers. Since these children remained incontinent between catheterisations, however, their lot was not greatly improved unless a bladder antispasmodic was added to the regimen.

Both Guttmann (I966) and Frankel (I974) at Stoke Mandeville and Pearman (I976) in Western Australia have performed intermittent catheterisation on spinal cord injured women, with the aim of enabling them to attain continence and the catheter free state. Bladder antispasmodic drugs were not used at that time and the patients frequently urinated in between voiding and had to wear diapers or incontinent pants. The logical next step therefore was to add a spasmolytic drug to abolish spontaneous detrusor function entirely so that the patient remained continent but relied on self-intermittent catheterisation as a permanent mode of bladder emptying. We began using this method 5 years ago and the present report describes our experience with the 24 women trained in this technique so far and the 17 who continue to practice it. 


\section{Selection of patients}

Any woman with a neurological bladder dysfunction and sufficient use of her hands is now considered for training. Some patients have to be rejected at the outset, however, on account of obesity, severe autonomic dysreflexia or poor motivation. Although a C6-7 tetraplegic patient may have sufficient hand function to be able to catheterise herself, transferring on and off a toilet four times a day requires a considerable expenditure of energy which some patients are not prepared to make. Moreover, the patients must wear skirts or make the extra effort to remove trousers, or tight jeans. The discharge plans and ability of the patient to find and use an accessible toilet must also be considered. These aspects have to be discussed with patients before starting the training procedure.

All but one of the patients reported in this study were already hospitalised at Highland View and all but two had been wearing Foley catheters before training. One paraplegic woman had started on SIC 2 weeks prior to her admission, and another rehabilitated, incomplete paraplegic had lost her ability to remain continent after discharge.

There were 17 traumatic spinal cord injuries (SCI) in the group, two patients with diabetic neuropathy, two with multiple sclerosis (M.S.) and one each with metastatic tumor of the spine, vascular lesion of the cord, and transverse myelitis (Table I). Eighteen of the women were paraplegic and four were tetraplegic. Three women had some limitation of hand function.

They ranged in age from 16 to 65 years (mean 36 years).

\section{Preliminary studies}

All selected patients had cystometric studies and urinalysis and cultures before training. The majority (19/24) also had intravenous pyelograms (IVP). Cystograms were performed on all but one of the spinal cord injury patients but on none of the medical patients.

\section{Training procedure}

The Foley catheter is removed early in the morning on the first day and urine sent for urinalysis and culture. The Catheter Team Supervisor visits the patient, goes over the procedure and fluid restrictions and gives her the training booklet. A fluid output record sheet is also given to the patient who is responsible for seeing that it is filled out every time she empties her bladder or voids incontinently. The supervisor then catheterises the patient using the standard no-touch

\section{TABLE I}

Underlying diseases in study patients

$\begin{array}{lr}\text { Traumatic spinal cord lesions } & \text { I7 } \\ \text { Vascular spinal cord lesions } & \text { I } \\ \text { Malignant spinal cord lesions } & \text { I } \\ \text { Multiple sclerosis } & 2 \\ \text { Diabetic neuropathy } & 2 \\ \text { Transverse myelitis } & \text { I } \\ \text { Total number of patients in study } & 24\end{array}$


Bacteruria \& SIC in 24 hospitalized women

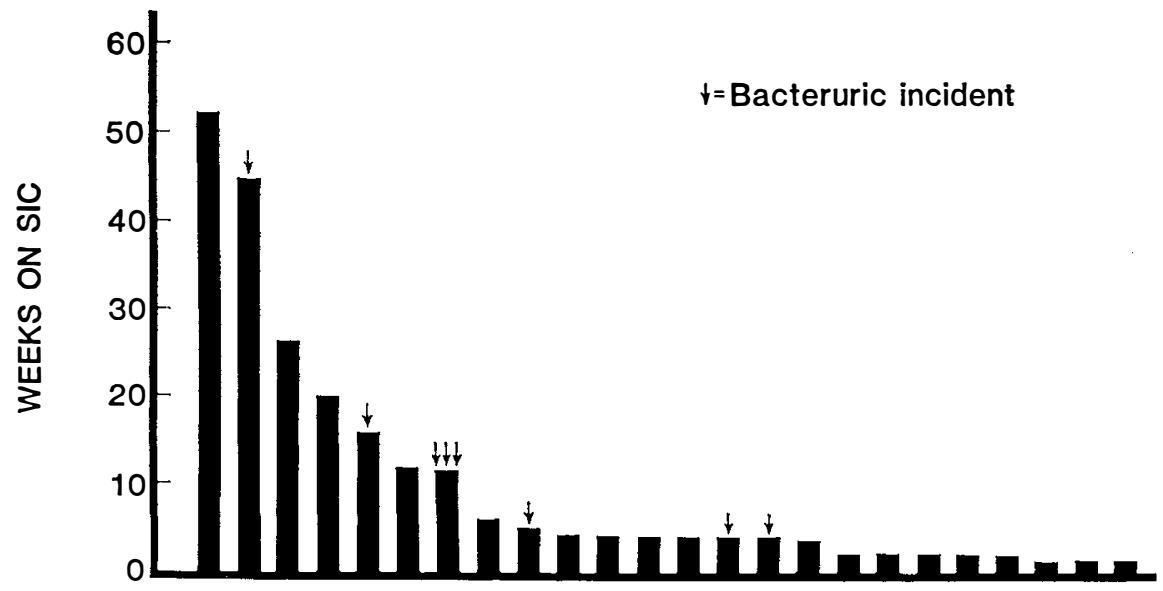

PATIENTS

FIG. I

Incidence of bacteruria in 24 women on self intermittent catheterisation while in hospital.

technique and a mirror, placed so that the patient can see what is being done. After this demonstration the patient performs all subsequent catheterisations herself in bed, at first under supervision and using the povidone-iodine cleansing agent, but with sterile gloves instead of forceps, and observing herself in the mirror. When she is judged competent and is able to transfer to the commode or toilet, she catheterises herself without the use of the mirror and with only a soap and water wash, to simulate how it will be done at home. While in hospital the patients are supplied with sterile catheters each time, although they may re-use cleaned, dry catheters at home. The patient catheterises herself four times daily, at 7.00 a.m., I 2 Noon, 5.00 p.m. and 10.00 p.m. Fluids are restricted in an attempt to ensure that there is not more than $400 \mathrm{ml}$ in the bladder at the time of catheterisation, and the usual intake is $100 \mathrm{ml}$ an hour between 7.00 a.m. and 9.00 p.m. (I $400 \mathrm{ml} /$ day).

This can all be taught to a rehabilitated patient in the out-patient clinic in one session. Newly injured patients, however, have to make adjustments to their altered sensory input and physical disability and therefore progress more slowly.

All patients with reflex detrusor activity were initially given oxybutynin chloride, $5 \mathrm{mg}$ every 6 hours, administered on an empty stomach. The dosage was then adjusted as needed to keep the patient dry. Three patients were able to remain continent on two or three doses only, but one required $20 \mathrm{mg}$ q. $6 \mathrm{~h}$. to avoid accidental incontinence.

\section{Suppressive antimicrobial therapy}

All patients had a sterile urine at the start of SIC, any urinary infection having been treated with a specifically indicated antibacterial drug before starting the training period. It has been the usual practice of the Spinal Cord Injury Unit to use low doses of an antibacterial drug during intermittent catheterisation, on 
the premise that this situation is analogous to that of the unparalysed woman with chronic recurrent cystitis (Table II). Physicians on other services, such as chronic medicine and neurology (diabetics and M.S. patients) usually elected to give no antibacterials unless an infection occurred.

\section{Follow-up studies}

Daily cultures and a weekly urinalysis and sediment examination were performed on all patients while in the hospital. Following discharge, spinal cord injury patients attended the clinic at 6-weeks post-discharge and at 6-month intervals thereafter. Flat plate X-rays of the abdomen and urine specimens were taken every 6 months and a pyelogram, BUN and creatinine obtained annually. Cystograms were performed only if there was any indication of abnormality on the pyelogram. In addition, patients were encouraged to attend the clinic or bring in a urine specimen at any time if they had any indications of infection, e.g., loss of continence or change in character of the urine. Patients who lived some distance away were supplied with 'Uricult' paddles which could be mailed in to the laboratory.

\section{Results}

Twenty of the 24 women successfully completed training and were discharged home on the self-catheterisation routine.

Four patients were discontinued while in hospital, for four different reasons. One patient was poorly motivated and less cooperative than had been anticipated; one diabetic post-stroke patient did not develop sufficient hand strength; one woman with a vascular lesion of the spinal cord had uncontrollable nocturnal diuresis and the fourth patient was a drug addict who failed to make a social readjustment. The remaining successful patients have been available for follow-up for periods of 3 months to 5 years (mean 20 months).

Following discharge, three of the remaining 20 patients have discontinued self-intermittent catheterisation. One patient with a birth defect of the spine elected to go back to her lifetime routine of diapering, apparently oblivious after all these years to the odour. Two other traumatic SCI patients elected to go back on Foley drainage because of social problems involved in getting to a toilet on schedule.

\section{TABLE II}

Suppressive antibacterial medications given to women patients on self-intermittent catheterisation

\begin{tabular}{ccccc}
\hline & MM & Nf & TMP-SMZ & O \\
$\begin{array}{c}\text { In hospital } \\
\text { 24 patients }\end{array}$ & 7 & 6 & 7 & 4 \\
$\begin{array}{c}\text { At home } \\
\text { I7 patients }\end{array}$ & 4 & 7 & 0 & 6 \\
\hline
\end{tabular}

MM-methenamine mandelate I gm q.i.d.

$\mathrm{Nf}$-nitrofurantoin $50 \mathrm{mg}$. q. $12 \mathrm{~h}$.

TMP-SMZ-trimethoprim-sulfamethoxazole I tab. q. I2 h. 
Urinary infections

There were no incidents of febrile urinary infections while the patients were in hospital nor during the follow-up period.

Over a total cumulative period of 238 patient weeks of hospitalisation, during which the 24 women entered in the study performed self-intermittent catheterisation, six women ( 25 per cent) developed significant bacteriuria ( $\geq 10^{5} \mathrm{CFU} / \mathrm{ml}$ accompanied by $\geq 20 \mathrm{wbc} / \mathrm{HPF}$ of spun urine) (Fig. I). A ten-day course of specific antibacterial therapy was given for each infectious incident, and there were no recurrences except in the case of a middle-aged, rather obese lady with multiple sclerosis, who experienced three incidents of e.coli bacteriuria at intervals of 4 weeks.

During a total cumulative period of 23.6 patient years following discharge, six of the I 4 women still using self-intermittent catheterisation (43 per cent) were found on routine follow-up visits to have significant bacteriuria (Fig. 2). Four of the six patients had two such incidents and one had three incidents.

Both in hospital and the outpatient clinic, the most commonly isolated organism was e. coli (nine incidents) with lesser numbers of proteus and klebsiella and an isolated incident of citrobacter bacteriuria. Eight patients showed transient colonisation with small numbers of pseudomonas or serratia while in hospital. These were not treated and disappeared after SIC was instituted. Only one patient has ever shown such colonisation after discharge when pseudomonads were cultured from one urine specimen at a clinic visit, but were not present at the following clinic visits.

\section{Other complications}

Overdistention of the bladder, defined as more than $500 \mathrm{ml}$ of urine in the bladder without any leaking, occurred during the hospitalisation period in six

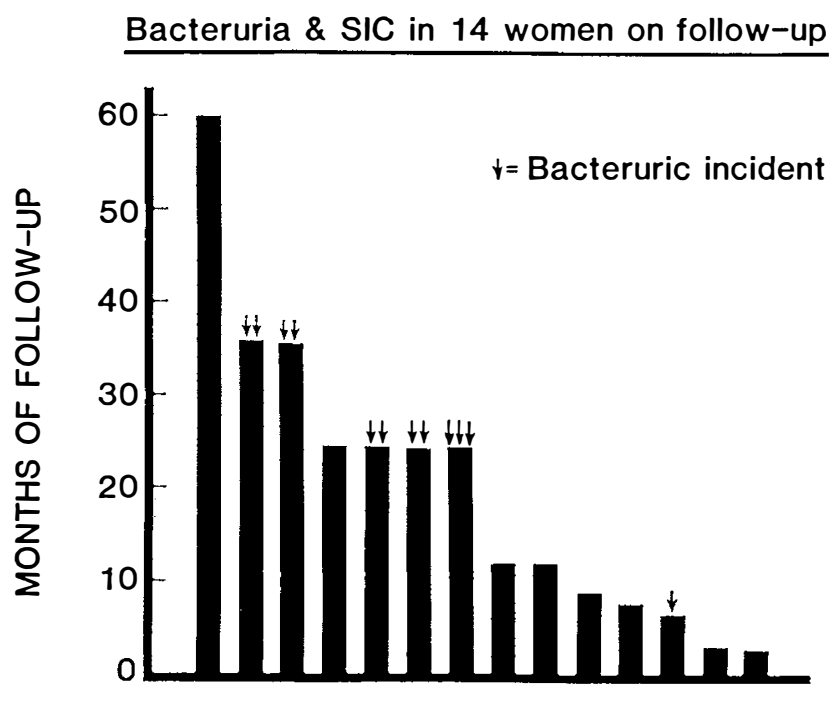

PATIENTS

FIG. 2

Incidence of bacteriuria in 14 women on self intermittent catheterisation following discharge from hospital. 
patients, two with traumatic cord lesions, two with diabetic neuropathy, one with M.S. and one with a vascular lesion of the cord, and it occurred on more than one occasion with the two diabetic patients.

Dilatation of the ureter and kidney pelvis occurred in two patients. In one woman who was admitted from the acute unit on intermittent catheterisation, bilateral dilatation and vesico-ureteral reflux was detected on admission examinations. Intermittent catheterisation was continued and I year later the pyelogram had returned to normal. The second patient had achieved continence but unilateral dilatation of ureter and pelvis was detected following childbirth. She was put back on intermittent catheterisation and the condition has resolved over a period of 6 months.

One patient had a single incident of haematuria without any identifiable cause. We have seen no urinary calculi developing during intermittent catheterisation.

\section{SUMMARY}

Self intermittent catheterisation (SIC) was taught to 24 women with neurological diseases involving the bladder. The major causes of neuropathic bladders were traumatic lesions of the spinal cord ( 17 cases, 70 per cent), diabetes and multiple sclerosis. Patients were aged I6-65 years (mean 36 years).

Initial acceptance of the procedure proved to be a temporary problem in some fastidious women, but the majority eagerly accepted the opportunity to be free of permanent drainage equipment.

A bladder relaxant drug was used in order to suppress spontaneous detrusor contractions in patients with intact lower motor neurones. A training period of I day to 2 weeks, depending on manual dexterity, was sufficient to ensure competence in the technique. All patients were able to perform the procedure with few incidents of infection while in the Hospital, but in four patients it proved to be impractical and was discontinued after I to 2 weeks. After discharge home three patients have gone back to permanent Foley drainage.

Women who have good home settings or who are able to ambulate to some degree, do well on SIC, but the advantages of prevention of infection and freedom from drainage bags do not, as yet, outweigh the social problems for many women confined to wheelchairs such as architectural barriers, time schedules and suitable clothing. Selected patients must be both well motivated and independent in transfers so that while an excellent solution for some, SIC is far from being the solution for all women with neurological dysfunction of the bladder.

\section{RÉSUMÉ}

On a enseigné a 24 femmes ayant des maladies neurologiques de la vessie de se catheteriser d'une façon intermittente (SIC). Les plus grandes causes des vessies neuropathiques sont des lésions de la corde épinale ( 17 cas, $70 \%$ ) diabete et sclerose multiple. Les malades etaient ageés de 16 a 65 ans (en moyenne 36 ans).

L'acceptation initiale de ce procedé a étè temporarement difficile chez certaines femmes, mais la majorité ont accepté cette opportunité avec joie d'être libre de drainage permanent.

Un medicament relachant les muscles de la vessie a étè préscrit, cela pour empêcher les contractions spontinées du muscle detrusor chez les patients dont les neurones inferieurs sont intacts. Une period d'entrainèment de I jour a 2 semaines, tout dependant de dexterité, etait suffisant pour assurer la competence dans la technique. Toutes les patients etaient capable d'executer le procedé parfaitement, avec peu d'infections pendant leur séjour a l'hôpital. Cependant le procedé s'avere impracticable chez 4 malades et fit abandonné aprés I à 2 semaines. Trois malades après être rendue à la maison, sont retournées au drainage permanent (Foley). 
Les femmes dont les familles offrent bons facilites, et le bon support, et les femmes qui sont capable de circuler se debrouillent bien avec ce procedé. Les avantages de la prévention d'infection et la liberté de rester en dehors des sacs de drainage ne contre balancent pas les problémes sociaux pour beaucoup des femmes confinées dans les chaises roulantes. SIC n'est pas la solution pour toutes les femmes avec une dysfonction neurologique de la vessie, et les malades selectionées doivent être motivées et independentes de transferts.

\section{ZUSAMMENFASSUNG}

24 Frauen mit neurogener Dysfunktion der Harnblase wurden Instruktionen gegeben sich selbst intermittierend zu katheterisieren. Die Ätiologie der Blasenlähmung war traumatisch ( 17 Fälle $=70 \%$ ), Diabetes und Multiple Sklerose. Die Patienten waren von 16 bis 65 Jahre alt (Durchschnittsalter 36 Jahre).

Zuerst akzeptierten einige sensible Frauen die Prozedur nicht gut, aber die meisten Frauen waren dankbar, ohne permanenten Katheter auskommen zu können.

In Patienten mit intakt gebliebenem unteren morotischen Neuron wurden Medikamente zur Blasenerschlaffung benutzt, um die spontanen Detrusor Kontraktionen zu vermeiden. Ein Tag bis zwei Wochen waren genügend, von der Geschicklichkeit abhängig, um die Technik zu lernen. Alle Patienten konnten die Katheterisierung im Krankenhaus ohne infektiöse Komplikationen ausführen. Drei Patienten aber fanden die Prozedur unpraktisch und gaben sie nach ein bis zwei Wochen auf.

Nach der Entlassung vom Krankenhaus nach Hause kehrten 4 Patienten wieder zum Foley Katheter zurück.

Frauen mit gutem Milieu zu Hause, oder Frauen die zu einem gewissen Grade gehen können, sind erfolgerich mit SIC, aber die Prozedur lohnt sich nicht, soweit wir jetzt sehen können, bei Frauen, die auf den Fahrstuhl angewiesen sind, mit sozialen Problemen wie architektonische Hindernisse im Haus, zeitliche Beanspruchungen, passende Kleidung, U.S.W.

SIC ist nicht die Antwort für alle Frauen mit neurogener Dysfunktion der Harnblase, und ausgewählte Patienten müssen gut motiviert und Fahrstuhl unabhängig sein.

\section{REFERENCES}

Bors, E. (1967). Intermittent catheterization in paraplegic patients. Urol. Int., 22, 236-249.

COMARR, A. E. (1972). Intermittent catheterization for the traumatic cord bladder patient, F. Urol., 108, 79-84.

Firlit, C. F., Canning, J. R., Lloyd, F. A., Cross, R. R. \& Brewer, R. Jr. (1975). Experience with intermittent catheterization in chronic spinal cord injury patients. F. Urol., 114, 234-236.

Frankel, H. L. (I974). Intermittent catheterization. Urol. Clin. N. Amer., I, I I5-I24.

GutTMANN, L. \& FRANkel, H. (1966). The value of intermittent catheterisation in the early management of traumatic paraplegia and tetraplegia. Paraplegia, 4, 63-84.

LApides, J., Dionko, A. C. \& Lowe, B. S. (I972). Clean intermittent self catheterization in the treatment of urinary tract disease. F. Urol., I07, 458-46I.

Lindan, R. \& Bellomy, V. (1975). Effect of delayed intermittent catheterisation on kidney function in spinal cord injury patients - a long-term follow-up study. Paraplegia, 13, 49-55.

Pearman, J. W. (1976). Urological follow-up of 99 spinal cord injured patients initially managed by intermittent catheterisation. Brit. F. Urol., 48, 297-310.

PERKASH, I. (1975). Intermittent catheterisation and bladder rehabilitation in spinal cord injury patients. F. Urol., 114, 230-233. 